Melvin J. Dubnick. 1991. American Government, 2nd ed. Boston: Houghton Mifflin.

Greenberg, Edward S. 1989. The American Political System: A Radical Approach, 5th ed. Glenview, IL: Scott, Foresman.

Greenberg, Edward S., and Benjamin I. Page. 1993. The Struggle For Democracy. New York: HarperCollins.

Havick, John. 1991. American Democracy in Transition: A Communications Revolution. St. Paul, MN: West.

Holmes, Jack E., Michael J. Engelhardt, and Robert E. Elder. 1991. American Government: Essentials and Perspectives. New York: McGraw Hill.

Janda, Kenneth, Jeffrey M. Berry, Jerry Goldman, and Earl Huff. 1990. The Challenge of Democracy: Government in America (brief edition). Boston: Houghton Mifflin.

Janda, Kenneth, et al. 1989. The Challenge of Democracy: Government in America, 2nd ed. Boston: Houghton Mifflin.

Keefe, William J., Henry J. Abraham, William H. Flanigan, Charles O. Jones, Morris S. Ogul, and John W. Spanier. 1990. American Democracy: Institutions, Politics, and Policies (3rd Edition). New York: Harper \& Row.

Ladd, Everett Carll. 1991. The American Polity: The People and Their Government, 4th ed. New York: W.W. Norton.

Le Loup, Lance T. 1991. Politics in America: The Ability to Govern (3rd ed.). St. Paul, MN: West.

Lineberry, Robert L., George C. Edwards III, and Martin P. Wattenberg. 1991. Government in America: People, Politics, and Policy, 5th ed. New York: Harper-Collins.

Lipsitz, Lewis, and David M. Speak. 1989. American Democracy, 2nd ed. New York: St. Martin's.

Lowi, Theodore J., and Benjamin Ginsberg.
1990. American Government: Freedom and Power. New York: W.W. Norton.

Lyons, William, Johgn M. Scheb II, and Lilliard E. Richardson, Jr. 1995. American Government: Politics and Political Culture. Minneapolis: West.

McKenna, George. 1990. The Drama of Democracy: American Government and Politics. Guilford, CT: Dushkin.

Moore, Jr., John A., and Myron Roberts. 1989. The Pursuit of Happiness: Government and Politics in America, 4th ed. New York: Macmillan.

O'Connor, Karen, and Larry J. Sabato. 1996. American Government: Roots and Reform, 2nd ed. Boston: Allyn and Bacon.

O'Connor, Robert E., Thomas G. Ingersoll, and Robert F. Pecorella. 1990. Politics and Structure: Essentials of American National Government, Sth ed. Pacific Grove, CA: Brooks/Cole.

Patterson, Samuel, Roger H. Davidson, and Randall B. Ripley. 1989. A More Perfect Union: Introduction to American Government, 4th ed. Pacific Grove, CA: Brooks/Cole.

Patterson, Thomas E. 1990. The American Democracy. New York: McGraw-Hill.

Prewitt, Kenneth, Sidney Verba, and Robert H. Salisbury. 1991. An Introduction to American Government, 6th ed. New York: HarperCollins.

Reynolds, H. T., and David Vogler. 1991. Governing America. New York: HarperCollins.

Ross, Robert S. 1991. American National Government: Institutions, Policy and Participation, 2nd ed. Guilford, CT: Dushkin.

Saffell, David C. 1989. Essentials of American Government: Change and Continuity. Pacific Grove, CA: Brooks/Cole.

Saye, Albert B., and John F. Allums. 1990. Principles of American Government, 11th ed. Englewood Cliffs, NJ: Prentice-Hall.
Sherrill, Robert. 1990. Why They Call It Politics: A Guide to America's Government, 5th ed. San Diego: Harcourt Brace Jovanovich.

Stone, Alan, and Richard P. Barke. 1990. Governing the American Republic: Economics, Law and Policies, 2nd ed. New York: St. Martin's.

Tannahill, Neal, and Wendell M. Bedichek. 1991. American Government: Policy and Politics, 3rd ed. New York: HarperCollins.

Volkomer, Walter E. 1995. American Government, 7th ed. Englewood Cliffs, NJ: Prentice Hall.

Wasserman, Gary. 1991. The Basics of American Politics, 6th ed. New York: HarperCollins.

Welch, Susan, John Gruhl, Michael Steinman, and John Comer. 1991. Understanding American Government. St. Paul, MN: West.

Wilson, James Q. 1990. American Government: Brief Version, 2nd ed. Lexington, MA: D.C. Heath

Wilson, James Q. 1992. American Government: Institutions and Policies, 5th ed. Lexington, MA: D.C. Heath.

Woll, Peter, and Robert H. Binstock. 1991. America's Political System: A Text with Cases. New York: McGraw-Hill.

Woll, Peter, and Sidney E. Zimmerman. 1989. American Government: The Core. New York: Random House.

\section{About the Author}

J. M. Sanchez is an associate professor of political science at Adelphi University. He has published articles on constitutional law and American political films. He is currently completing research on the activities of former presidents.

\title{
Local News, Presidential Campaigns, and Citizenship Education: A Reform Proposal
}

\author{
Robert N. Roberts and Anthony J. Eksterowicz, James Madison University
}

The 1992 presidential election campaign highlighted the ability of national campaigns to bypass experienced national political reporters. Both the Bush and Clinton campaigns used the latest technology to send their messages to local media markets across the country. Satellite hookups permitted campaign spin doctors to tailor their messages to local audiences and to interact with local news personalities. Equally important, the candi- dates participated more frequently in participatory news and talk programs. George Bush and Bill Clinton appeared on television talk shows like Larry King Live, The Phil Donahue Show, and radio call-in shows such as Immus In the Morning and Rush Limbaugh (Rideout 1993, 712).

Despite the excellent political coverage in many daily newspapers, the decline in newspaper readership makes citizens more de- pendent upon television and radio for political information (Robinson $1980,219)$. When politicians tailor political campaigns to local audiences, they heighten the role performed by local news people and talk-show mavens in interpreting the message sent to potential voters.

The ability of politicians to go over the heads of national and local media has raised serious questions regarding the media's ability to pro- 
vide objective information regarding candidates' positions. Despite efforts to increase coverage of substantive issues, the media all too often fall back to the practice of treating each campaign as a horse race driven by public opinion polls. If the national media find it difficult to avoid turning elections into a sporting event, the local media face even more serious problems. Put simply, do local media outlets and their news people have the ability to scrutinize political campaigns?

The question can also be asked of media reporting on a wide range of issues. Today, serious doubt exists as to whether schools of communication and journalism adequately prepare their graduates to deal with the complex issues they will face.

Schools of journalism and mass communication generally require of their majors too few public affairs, government, or political science courses, leaving their graduates ill prepared to cover politics. Colleges and universities with journalism and mass communication programs need to establish political communication minors to prepare their graduates for the complexities of political journalism.

\section{Mass Communication Education and American Higher Education}

Those wishing to enter the field of print or broadcast journalism, through the first half of the twentieth century, rarely graduated from college with degrees in journalism or mass communication. Most often they left college with degrees in English, history, philosophy, or other degrees from the humanities or social sciences. The explosion in higher education after the Second World War led to the proliferation of pre-professional undergraduate programs including journalism and mass communication (Crook 1995. 4-15). The last three decades have seen an explosion in the number of graduates from schools of journalism and communication.

Largely because of the breakthroughs in communication technol- ogy, students of journalism and communications are spending more hours in the classroom studying the process of collecting and delivering the news. Media organizations expect individuals they hire to know how to write a news story or to put together a segment for a nightly news broadcast (McCorkle 1991, 37).

The proliferation of journalism and mass communication programs has not gone unchallenged. Critics of the trend argue that a broad education provides potential journalists with a more diversified background for covering local, state, and national issues. The faculty of the University of Michigan, for example, recently recommended dropping undergraduate journalism courses from the curriculum in order to focus on graduate journalism education (Fitzgerald 1995, 13, 38).

More common than efforts to drop journalism courses are proposals to encourage mass communication and journalism students to take more nonjournalism courses (Garneau 1990, 16). This concern has helped to foster a debate over the role of liberal arts courses within journalism and mass communication curricula (Ioria and Williamson 1995, 16). Because graduates of journalism and mass communication programs face increased pressure from prospective employers to hit the ground running, it is highly unlikely that many universities will abolish these programs.

The guaranteed long-term role of schools of journalism and mass communication as the primary source of new recruits for print and broadcast organizations does not mean that colleges and universities can ignore the need to better prepare their graduates to help educate the nation about the operation of political institutions.

\section{The Progressive Era and the Rise of Professional Journalism}

The late nineteenth-century progressive movement ushered in a new era of participatory democracy. Progressives lobbied vigor- ously for the enactment of various "good government" reforms that included the short ballot, direct citizen initiative and referendum, line item budgets, tax limitations, and nonpartisan elections for many local positions (Cronin 1989, 38-59).

Growing public concern over the power of big business and political machines helped to lay the foundation for a new, more aggressive, "muckraking"' style of journalism. Newspapers found that a receptive audience existed for aggressive investigative journalism-a growing middle class that wanted improved public services and more responsible conduct by American business.

The first half of the twentieth century saw the print media assume unprecedented power in shaping the political fortunes of national and state political candidates. Despite the rise of radio as the first avenue of real-time mass communications, political campaigns realized that the fraternity of well-seasoned national political reporters and columnists had the ability to shape election coverage (Bonafede 1980, 564).

\section{Television and Presidential Campaigns}

The rise of television after the Second World War irrevocably changed the social, cultural, and political landscape of the country. Television has become the primary source of news for the majority of the American people. Television coverage of the Viet Nam War, for example, played a crucial role in turning national public opinion from strong support to one of growing alarm over the inability of the strongest military power in the world to stop a Third World country from challenging the authority of the United States to allocate political power in far-off lands.

Presidential candidates learned that the mastery of television and the ability of their campaigns to shape news coverage contributed to a successful campaign. Donovan and Scherer $(1992,27)$ note that, in 1960 , Nixon learned that he had, ". . . concentrated too much on substance and not enough on ap- 
pearance." Joe McGinnis (1969) in his classic work, The Selling of the President, documented the steps the Nixon campaign took during his successful 1968 presidential campaign to shape media coverage. The campaign staged events and photo opportunities and recruited sympathetic audiences.

The 1976 presidential campaign saw Jimmy Carter, like Richard Nixon, focus on symbolism rather than substance. Carter, however, constructed his campaign from the grassroots. While the national media focused on well-known national political figures, Carter directed his efforts at sending his message through local media outlets (Bonafede 1980,560 ).

In the 1980 s, the Reagan and Bush campaigns continued efforts to control the message transmitted by the national media to the American people. Reeling from criticism for failing to hold political campaigns accountable for their campaign practices during the 1970 s, national television reporters in the 1980s attempted to limit their coverage of staged candidate events. Media sound bites of campaign coverage were reduced from one to two minutes in 1968 to, on average, 8.9 seconds in 1988 (Hallin 1991, 34).

Controlling the spin placed on campaign events became as important as the events themselves. Countless experts analyzed how well nominees presented convention speeches or performed in presidential debates. Getting an unfiltered message through to undecided voters became an increasingly difficult process for presidential campaigns.

\section{The Clinton Campaign and the New Technology}

The ability of Bill Clinton to rise from the proverbial dead during the 1992 presidential campaign can be explained, in part, by his ability to pass over the national media with his message of symbolic change. In fact, the Clinton campaign monitored satellite network news feeds which helped the campaign respond, within hours, to negative reports or accusations by the Bush campaign (Walsh 1992, A10). Clinton devoted countless hours to town meetings and talk shows designed to persuade voters that he understood their problems (Rideout 1993, 712). This theme played well with an increasingly alienated electorate.

Finally, the Clinton campaign used satellite technology to supply local news stations with campaign material including one-on-one interviews with Clinton or surrogates (Walsh 1992, A10). Direct access to local news outlets helped Clinton to overcome the early negative coverage of his candidacy which came close to knocking him out of the race.

Some of these campaign techniques have been used by the Clinton White House in its efforts to govern (Kurtz 1993c, A13), and the perils associated with this have been explored by Eastland (1993, 100-105). For example, President Clinton faced sharp rebukes from the public when he reneged on a middle class tax cut and a campaign pledge to allow Haitians into the country during a town hall meeting in Michigan with satellite hookups to audiences in Miami, Atlanta, and Seattle (Devroy 1993, A1, 18).

Outside traditional print and broadcast journalism, a huge industry has emerged to aid political campaigns, public citizens, and private campaigns in their efforts to shape media coverage or limit the damage to their clients resulting from negative media reporting. Journalists are now facing intense pressure from political actors and interest groups to present the news favorable to their interests.

\section{The Impact of Local News}

Ever since the 1960s, journalists and presidential campaigns have battled for control of campaign agendas. Local television news stations are increasingly playing a role in reporting national events from a local perspective. Today, interaction between journalists and presidential campaigns occurs increasingly within a local context.

There are economic reasons for this phenomenon. As Hallin (1992, 35; 1991, 43-46) notes, network news divisions learned from their local news divisions that increasingly negative campaign coverage generates revenue. The expansion of local news operations helped local news become the profit center for many local stations.

There are also technological reasons for the increasing importance of local news. Electronic news gathering (ENG) and satellite news gathering (SNG) allow local news stations to compete with national news networks in covering breaking news stories. The advent of independent news bureaus that report on the Washington scene and then contract out to local television news stations has also increased the ability of local stations to cover Washington from a local perspective (Matlack 1989, 393).

Critics maintain that increasing competition for news audiences forces television news, both national and local, to search for drama to hold the attention of audiences (Lacy et al. 1988, 925-66). The practice of contracting out for news can also blur the lines between journalism and salesmanship (Matlack 1989, 393).

Presidential candidates and their managers justify the new emphasis upon local television news interviewing and national call-in talk shows as a broad effort to reach the people (Kurtz 1993b, A4). If the national media refuse to broadcast sound bites and cover staged campaign events, campaigns have little choice but to court the local news media (Kaus 1992, 16), which have few problems with presenting campaign sound bites. After all, stations receive increased advertising revenue, and the public gains greater respect for local news personalities-but not necessarily greater knowledge of issues that surround the campaign.

The practices of local news stations such as covering national events from a local perspective has contributed to the nationalization of local news. The growing financial rewards of local news makes it likely that this practice will continue (Quinn 1993, D10). These profits permit stations to hire more 
news personnel and provide news departments with larger budgets (Ostroff and Sandell 1989, 114-20). Local news operations have more time and resources to cover national news stories from their local perspectives. The public, more importantly, appears to prefer local over national news coverage (Bartlett 1993, 20).

Furthermore, technology will continue to aid local news stations. Many local news television stations now have their own satellite and electronic news-gathering vehicles (Lacy et al. 1988, 925-66). Practically all television stations receive network feeds through satellite dishes.

\section{The Quality Issue}

Serious questions exist about the quality of local news coverage of presidential campaigns. Presidential candidates target local news people for interviews because of the widely held perception that local reporters will be kinder and gentler than national reporters. In fact, many local news outlets, like some of their national counterparts, cover presidential speeches with almost no significant analysis of issues.

High turnover rates among television reporters makes it difficult to develop expertise in political reporting. Stations consequently send inexperienced reporters to cover campaign events. The lack of expert reporting gives candidates a greater opportunity to dictate the extent and quality of campaign coverage (Ostroff and Sandell 1989, 114-20).

These problems are compounded by others, such as the pressure for large audiences which seems to dictate news stories with compelling visuals that political stories often lack. Thus political coverage suffers (Kern and Wicks 1994, 195).

Future presidential campaigns will see the public receive more of their information about candidates from local media outlets. The public will expect their local stations to inform them about the local effects of national and international political and economic events. Without a better understanding of economics, international affairs, domestic policy, and other public policy issues, local reporters will find it increasingly difficult to explain the positions of candidates for elective office on important public policy issues. No amount of on-the-job training can substitute for knowledge of world affairs.

\section{The Education of Communication Majors: A Proposal}

Although many graduates of communication and journalism schools still seek employment with newspapers and magazines, many more seek employment in television and radio, especially as on-air reporters or news anchors.

The larger the market, the more likely the station will permit reporters to develop a specialization. Many stations, for example, have reporters assigned to deal with criminal justice and legal issues, health issues, consumer affairs, financial matters, education, and cultural events. Despite the growing trend towards specialization in local broadcasting, few communication programs require majors to specialize in substantive areas.

The typical mass communication major takes a core set of courses dealing with the role of mass communications in society and concentration in fields such as journalism, electronic media production, or corporate media. Common courses include electronic news writing, television production, news editing, and feature writing. Mass communication departments spend a great deal of time making sure that graduates have the technical competence to report and produce news stories. Many mass communication departments encourage students to take a wide range of courses outside their departments.

Print and broadcast journalists, historically, developed substantive public policy expertise through onthe-job training. Newspapers reporters learned about the criminal justice system by covering the courthouse and hanging around the police station. Television reporters learned about education by reporting on school board meetings.

Until fairly recently, inexperienced print or broadcast journalists started their careers with small newspapers or magazines and then moved up to larger publications or into larger radio and television media markets. Going from local markets to a national network has been the dream for many broadcast journalists.

The tremendous growth in the profitability of local broadcast news operations has provided local broadcast stations with the ability to pay higher salaries to recruit and retain personnel. The reduction in the size and influence of network news has reduced the number of positions for ambitious broadcast journalists. Local stations, more important, have found a market for their news stories beyond their broadcast area.

A November 1989 Time Magazine article chronicled the revolution in local news operations. Besides reporting upon the growing profitability of local news operations, the article discussed that 220 broadcast stations formed a partnership with Cable News Network to provide stories to the local stations, which in turn provided stories to the network (Castro 1989, 72-73).

The rapidly increasing professionalism of local broadcast news operations, consequently, provides strong support for requiring mass communication graduates to develop substantive areas of expertise before completing their undergraduate education. This is particularly true with respect to providing the mass communication major with the opportunity to develop a specialization in political affairs.

\section{Public Affairs Related Courses and Communication Majors}

A review of the curriculum requirements of the top U.S. communication programs as listed in the 1989 Gourman Report: A Rating of Undergraduate Programs in American and International Universities reveals that few require majors to 


\section{TABLE 1}

Public Policy Related Requirements in Selected Communication Programs

\begin{tabular}{|c|c|c|c|c|c|c|}
\hline \multicolumn{7}{|c|}{ Sampling of top US undergrad programs in Mass Comm./Comm. } \\
\hline Institution & Course Name & $\mathrm{Cr}$ & MR & ME & $\mathrm{P} / \mathrm{I}$ & EP \\
\hline U. Washington & The Press and Politics & 5 & & $\mathrm{XX}$ & & \\
\hline Ohio State U. & Rhetoric of American Issues & 4 & & $\mathrm{XX}$ & & \\
\hline U. Penn/Annenberg & $\begin{array}{l}\text { Intro to Political Comm/TV } \\
\text { and Politics in US }\end{array}$ & & $\mathrm{XX}$ & & & \\
\hline & $\begin{array}{l}\text { Argumentation and Public } \\
\text { Advocacy }\end{array}$ & & & $\mathrm{XX}$ & & \\
\hline & Pol and Ritual in the Media & & & & $\mathrm{XX}$ & \\
\hline U. Minn., Minneap. & Mass Media and Pol & & & $\mathrm{XX}$ & & \\
\hline U. Wisc., Madison & See appendix & & & & & \\
\hline & $\begin{array}{l}\text { Topics in Gov't and Mass } \\
\text { Media }\end{array}$ & & $\mathrm{XX}$ & & & \\
\hline & Political Comm. & & & & & $\mathrm{XX}$ \\
\hline Mich. St. U. & See appendix & & & & & \\
\hline & Comm. Campaign Analysis & 4 & & $\mathrm{XX}$ & & \\
\hline Purdue U. & $\begin{array}{l}\text { Public Policy in Telecomm. } \\
\text { Controversy in Am. Society }\end{array}$ & 3 & $\mathrm{XX}$ & $\mathrm{XX}$ & & \\
\hline Syracuse U. & Specialized Reporting & & & $\mathrm{XX}$ & & \\
\hline U. So. Cal. & $\begin{array}{l}\text { Social Responsibility of the } \\
\text { News Media }\end{array}$ & & & $\mathrm{XX}$ & & \\
\hline U. Iowa & Pursuasion in Society & & & $\mathrm{XX}$ & & \\
\hline & Comm and Contemp Culture & & & $\mathrm{XX}$ & & \\
\hline & Rhetoric and Pol & & & $\mathrm{XX}$ & & \\
\hline & Studies in Political Comm & & & $\mathrm{XX}$ & & \\
\hline Northwestern U. & $\begin{array}{l}\text { Comm and American } \\
\text { Democracy }\end{array}$ & & & $\mathrm{XX}$ & & \\
\hline U. Texas & Intro to US Gov't & 3 & $\mathrm{XX}$ & & & \\
\hline & US Gov't Policy & 3 & $\mathrm{XX}$ & & & \\
\hline & Rprting Urban News & 3 & & $\mathrm{XX}$ & & \\
\hline Stanford U. & Political Comm. & 4 & & $\mathrm{XX}$ & & \\
\hline Florida St. U. & See appendix & & & & & \\
\hline & Pol Comm and Campaigning & 3 & & $\mathrm{XX}$ & & \\
\hline U. Mich., Ann Arbor & Public Affairs Reporting & 3 & & $\mathrm{XX}$ & & \\
\hline & Politics and Adv. Discourse & 3 & & $\mathrm{XX}$ & & \\
\hline & Pol and Mass Media & 3 & & $\mathrm{XX}$ & & \\
\hline & Comm and Public Opinion & 3 & & $\mathrm{XX}$ & & \\
\hline U. Mass, Amherst & Public Strategies & & & $\mathrm{XX}$ & & \\
\hline & Press and Politics & & & $\mathrm{XX}$ & & \\
\hline SUNY, Buffalo & No applied program & & & & & \\
\hline $\begin{array}{l}\text { U. Kansas, and } \\
\text { U. Missouri, } \\
\text { Columbia }\end{array}$ & $\begin{array}{l}\text { Top } 20 \text { grad programs, no } \\
\text { undergrad }\end{array}$ & & & & & \\
\hline
\end{tabular}

take established public affairs or public policy related courses.

Table One illustrates the public policy requirements associated with the top communication departments in prestigious American universities. The table depicts the university and the public policy courses associated with its communication program. The table also indicates whether that course is a communication major requirement, a major elective, an interdisciplinary political science course, or an elective offered by the political science department. For further information on these courses please see the appendix.

The analysis in Table 1 of some of the top programs in the United States indicates that students can graduate from many of these programs without taking courses designed to provide them with a working knowledge of substantive areas of government, economics, political science, political behavior, and public policy.

\section{Civic Journalism, Political Affairs,} and the Communication Majors

One can make a persuasive argument that this situation leaves many graduates of mass communication programs unprepared to produce well-informed stories or reports on public policy issues. Even if technically competent to report on political affairs, the lack of substantive knowledge on the day-today workings of government makes it difficult for many print and electronic journalists to provide the public with an understandable explanation for the behavior of political institutions and public officials. Print and broadcast journalists have become increasingly dependent upon "experts" for color commentary. Journalists, however, often do not have the training to distinguish between informed and uninformed experts.

To the anguish of newspapers and broadcast outlets, the public seems to be growing tired of journalists who simply show a video tape of the latest murder or report the latest decline in test scores. Increasingly alienated from their appointed and elected officials, the public now expects the media to become directly involved in helping to develop solutions for problems.

The National Civic Review published an article entitled, "The Dawn of Public Journalism" by Ed Fouhy, executive director of the Pew Center for Civic Journalism in Washington, D.C. The article describes the rise of public or civic journalism (Fouhy 1994, 259), which requires journalists to enter into a direct dialogue with their readers and listeners.

Civic journalism, according to Fouhy, "is about the whole range of issues that make up the public agenda of a community. It broadens a newspaper's focus from one dominated by political and governmental news to include more issues of interest to citizens who are neither members of the policy-making elite nor part of the political cognoscenti." The National Journal, during the summer of 1994 , reported on the nationwide spread of civic journalism (Pierce 1994, 1,585).

Defenders of public journalism emphasize the obligation of journalists to provide the public with information vital to an informed debate of the issues. "It provides the information people need to engage in informed discussion of the items on that agenda," states Fouhy, "as well as to facilitate public decisions, even if journalists must cre- 
ate the public space where those decisions are discussed" (Fouhy, 261-62).

Public journalism, within the journalistic community, has come under severe criticism (Stein 1995, 18). The most vocal critics argue that civic journalism gives the public too great a say in deciding what stories a newspaper or television station covers (Case 1994, 14). Journalists have an ethical responsibility to report the news and, from this perspective, cross the line when they become directly involved in trying to set political agendas. The fact remains, whether one supports or opposes the public journalism major, that graduates of mass communication programs often enter their chosen profession ill-equipped to provide the public with an accurate understanding of the complexities of public policy problems.

\section{The Political Communication Concentration: An Example}

The Department of Political Science and the Department of Human Communications at James Madison University, during the 1994-95 academic year, established an interdisciplinary political communication minor to provide students with conceptual applied knowledge in the fields of public and private interest groups and political campaigns. The program is designed for those students wishing to supplement their major programs with an emphasis upon communication skills specifically relevant to participation in political environments.

The core curriculum of the minor includes United States Government, Introduction to the Theories of Communication, State and Local Government or Urban Politics, Media and Politics, and an internship.

The minor also requires students to select one or two tracks. The Interest Group Track includes Interest Groups and Public Policy, and Communication and Social Movements. The Political Campaign Track includes American Political Campaigning and Political Communication II.

\section{Conclusion}

Many critics of our political system argue that, unless we do a better job educating the electorate, politicians will continue to evade dealing with difficult issues. Candidates will continue to base their campaigns on convincing voters that their opponents are unqualified to hold public office instead of explaining how they plan to address the concerns of the voters.

Colleges and universities that educate individuals to assume responsible positions in print and broadcast journalism have a responsibility to help students understand the nation's political institutions. If their graduates enter print and broadcast journalism without an understanding of the foundations of our political institutions, the media will lack the ability to improve their coverage of political affairs.

\section{Appendix}

The following details were extracted from information provided by each of the respective universities as of November 1993.

Most, if not all, schools listed have college or major requirements that require a minimum number of credits to be selected from the areas within social sciences, but there is little or no specificity as to which courses to select. Listed here are undergraduate elective or required courses by the various university communication departments along with any electives or requirements recognized by the department that are offered by the Political Science Department.

In brief, the following is a list of electives and requirements dealing with government and political science from Communication Departments that offer degrees likely to be pursued by students interested in reporting or journalism careers. We have not concentrated upon the "how to" types of science/ government courses. Please note that social science electives usually must be met in order to be admitted into a major. The following are major requirements and electives. It is possible that a student has been exposed to political science/government type courses without the formal encouragement of the individual Communication Departments.

The University of Washington offers a five-credit course entitled The Press and Politics. This course is not required but it is offered by the Communication Department on an elective basis. There are no political science type course requirements with the exception of this one elective within the department and any others from the Political Science Department as electives counting towards 35 credits required in the social science area.
Ohio State University offers a four-credit course entitled, Rhetoric of American Issues and a five-credit graduate course (open to undergraduates) entitled, Issues and Images in Political Communication. These two courses, offered by the Communication Department, are considered electives within the major.

The University of Pennsylvania Annenberg School of Communication offers several thematic clusters allowing students to select three courses from one department in one cluster and three courses from across departments in a second cluster. Three of the eight clusters recognize political science courses. These clusters are Communications and Politics, Communication Policy, and Communications in Society. Students must also choose two core courses from a list of four which includes a course entitled, Introduction to Political Communication/Television and Politics in the United States. This course can be considered an elective or a requirement. Additional courses offered as electives are Argumentation and Public Advocacy and a one-time interdisciplinary course entitled, Politics and Ritual in the Media.

The University of Minnesota, Minneapolis offers one elective "enrichment" type course entitled, Mass Media and Politics.

The University of Wisconsin, Madison requires students to take one course from each of three different departments (out of a list of eight Social Science Departments including political science). Students must select at least one course from either economics or political science. If students select a political science course instead of economics then they may select from a list of six political science department offerings. Another course requirement is that students must choose one course from the Mass Communication Institutions cluster, which contains three departmental courses including Topics in Government and Mass Media. Additional electives accepted by the department include a political science course entitled, Political Communication.

Michigan State University requires students to complete a six-course cognate (18-24 credits) in the behavioral and social sciences. Students must choose three of the four departments. One of these departments is political science, which offers 14 approved courses. The communications department offers one elective, a four-credit course entitled, Communication Campaign Analysis. The department also recognizes an external cognate known as Emphasis in Prelaw and Professional School. This emphasis includes three political science courses to select among a list of 13 , but this is not a Communication Department cognate but rather more of an optional concentration.

Purdue University offers a three-credit course entitled, Public Policy in Telecommunications, which is one of five courses in a required block where at least one course from each of the two blocks must be selected for a total of three courses. Other departmental electives are Controversy in American Society and a graduate-level course (open to undergraduates with consent) entitled, Communication in Politics. 
Syracuse University/S.I. Newhouse School of Public Communication requires students to take any two departmental electives, which may include Advanced Reporting or Specialized Reporting where the "hows" of public affairs reporting are covered. This does not appear to be a strict course on public affairs.

The Communication Department at the University of California offered no political science electives or requirements that were evident other than possibly a course entitled, Social Responsibility of the New's Media.

The University of Iowa offers departmental electives of Persuasion in Society, Communication and Contemporary Culture, Rhetoric and Politics, The Rhetoric of SelfJustification, and Studies in Political Communication. These courses all have some sort of political focus.

Northwestern University requires students to take one or more courses in the areas of economics, history, literature, math/science, and political science or economics. There is also an elective six-course concentration in one of these areas. In addition, the program requires the student to choose three courses from an approved list of 14 which includes one political science related course entitled, Communication and American Democracy.

The University of Texas requires 15 total credits in social sciences for graduation but this may, in all likelihood be a college requirement. The core required courses include six credits of government type courses. In addition a core course entitled, Reporting Urban News, is required. This course appears to be about a reporter's hands-on learning experience concerning how journalists work in a universe surrounded by and often guided by scores of government agencies.

Stanford University requires students to select a minimum of three courses from a list of eight which includes a four-credit course entitled, Political Communication.

Florida State University offers degrees in Media Performance and Media Communication. Each major requires a minor or a 15 hour interdisciplinary concentration in one field to be selected from journalism, meteorology, theater, English, political science, business, psychology, sociology, government, education, etc. Media Communication majors are required to select a minimum of nine hours, maximum of 15 from a list of seven courses. Three courses are already selected for students out of the list while the other four courses can be avoided. One of the courses is entitled, Political Communication and Campaigning.

The University of Michigan, Ann Arbor offers three-credit departmental electives entitled, Public Affairs Reporting, Politics and Advertising Discourse, and Mass Media and Communication and Public Opinion.

The University of Massachusetts, Amherst offers electives entitled, Public Strate- gies and Press and Politics. It also offers a 15-credit minor or concentration with the three most popular being (in order of popularity) English, history and political science.

S.U.N.Y. at Buffalo has no applied program, only one journalist/broadcast type course.

Kansas University has a top 20 communication graduate program but no undergraduate program.

The University of Missouri, Columbia has a top 20 communication graduate program but no undergraduate program.

\section{References}

Bartlett, David. 1993. "Viewers Like It." American Journalism Review. September, 20.

Bonafede, Don. 1980. "Catering to Political Reporters-A Must for Presidential Candidates." National Journal 12:560-64.

Case, Tony. 1994. "Public Journalism Denounced." Editor \& Publisher. November 12:14-15, 45 .

Castro, Janice. 1989. "The Sky's the Limit: Using Satellites and Other Technology, Local Television News Operations Are Boosting Profits and By Passing Networks." Time Magazine. November 27, 72-73.

Crook, James A. 1995. “1940's: Decade of Adolescence for Professional Education." Journalism \& Mass Communication Editor 50:4-15.

Cronin, Thomas E. 1989. Direct Democracy. Cambridge: Harvard University Press.

Devroy, Ann. 1993. "TV Public Puts Clinton on Defensive." The Washington Post, February 11, A1-18.

Donovan, Robert J., and Scherer, Ray. 1992. "Politics Transformed." The Wilson Quarterly. Spring:19-33.

Eastland, Terry. 1993. "The Dangers of a Talk Show Presidency." The World \& I. March:100-105.

Fitzgerald, Mark. 1995. "Faculty Recommends Dropping Undergraduate Journalism Courses." Editor \& Publisher 128: 13,38 .

Fouhy, Ed. 1994. "The Dawn of Public Journalism." National Civic Review. Summer-Fall:259-66.

Garneau, George. 1990. "Take More NonJournalism Courses." Editor \& Publisher 123 (April 14): 16.

Hallin, Daniel C. 1991. "Whose Campaign Is It Anyway?' Columbia Journalism Review 29:41-46.

Hallin, Daniel C. 1992. "Sound Bite Democracy." The Wilson Quarterly (Spring):34 37.

Ioria, Sharon Hartin, and Williamson, Keith. 1995. "The Role of Liberal Arts Courses Within Communication Curricula." Journalism and Mass Communication Educator 50(Spring):16-25.
Kaus, Mickey. 1992. "Sound-Bitten." The New Republic. October 26, 16, 18.

Kern, Montague, and Wicks, Robert $\mathrm{H}$. 1994. "Television News and the Advertising-Driven New Mass Media Election: A More Significant Local Role in 1992?', in The 1992 Presidential Campaign: A Communication Perspective, ed. Robert E. Denton Jr. Westport: Praeger.

Kurtz, Howard. 1993a. "News Media Hammer Soft Tosses," The Washington Post, January 22.

- 1993b. "Inaugurating A Talk Show Presidency," The Washington Post, February $12, \mathrm{~A} 4$.

. 1993c. "White House Monitors TV News Feeds," The Washington Post, April 16, A13.

Lacy, Stephen, Tony Atwater, and Angela Powers. 1988. "Uses of Satellite Technology in Local Television News." Journalism Quarterly 65:925-66.

McCorkle, William L. 1991. "A Primer for J-School Profs." Editor \& Publisher 124: 37, 44.

Matlack, Carol. 1989. "Live From Capitol Hill." National Journal 21:390-94.

McGinnis, Joe. 1969. The Selling Of The President. New York: Simon and Schuster.

Ostroff, David H., and Sandell, Karin L. 1989. "Campaign Coverage by Local TV News in Columbus, Ohio 1978-1986." Journalism Quarterly 66:114-120.

Pierce, Neal R. 1994. "Civic Journalism: A New Genre." National Journal 26 (July 2): 1,585.

Quinn, Michelle, 1993. "Tonight at 6 and 11: News and Cash Prizes," New York Times, August 9, D10.

Rideout, Christine F. 1993. "News Coverage and Talk Shows in the 1992 Presidential Campaign." PS: Political Science and Politics 26:712-16.

Robinson, John P., and Jeffres, Leo W. 1980. "The Great Age Readership Mystery." Journalism Quarterly 58:219-24.

Stein, M.L. 1995. "Beware of Public Journalism." Editor \& Publisher (May 6): 18.

Walsh, Edward. 1992. "High Technology Keeps Faraway HQ in Contact," The Washington Post, September 21, A10.

\section{About the Authors}

Anthony J. Eksterowicz teaches American political institutions at James Madison University. He is the coauthor of American Democracy: Representation and Participation in the Future of the Republic (Prentice. Hall 1995).

Robert N. Roberts teaches political science and public administration at James Madison University. He is the author of White House Ethics (Greenwood 1988). 